\title{
Ultrasound-assisted Supramolecular Microextraction of Copper in Water, Food, Hair, and Tobacco Samples Prior to Microsampling Flame Atomic Absorption Spectrometry
}

\author{
Z.A. ALOthman ${ }^{a}$, M.A. Habila ${ }^{a}$, E. Yilmaz ${ }^{\text {, }}$, and M. Soylak ${ }^{c, *}$ \\ a Chemistry Department, College of Science, King Saud University, Riyadh-11451, Kingdom of Saudi Arabia \\ b Faculty of Pharmacy, Department of Analytical Chemistry, Erciyes University, Kayseri, Turkey \\ c Erciyes University, Faculty of Sciences, Department of Chemistry, 38039 Kayseri, Turkey
}

\section{INTRODUCTION}

A trace amount of copper $(\mathrm{Cu})$ at the $\mu \mathrm{g} / \mathrm{kg}$ level is essential for human health, whereas high levels become toxic $(1,2)$. It plays an important role for renewable red blood cells and for enhancing some of the enzyme activities (3). Excess copper leads to DNA damage and disturbance in neuronal cells. In addition, free radical formation is usually accompanied with high concentrations of copper $(4,5)$. The main exposure to copper may be from drinking water or contaminated food. Leaky or corroded water pipes are often the main sources for copper in drinking water (6). The traditional determination of copper is by flame atomic absorption spectrometry (FAAS) or inductively coupled plasma mass spectrometry (ICP-MS) without pretreatment but suffers from matrix problems. The purification and preconcentration steps in the analytical methods increase the concentration of the targeted analyte and reduce interference (7). The common preconcentration methods are solid phase extraction (8), dispersive liquid-liquid microextraction (9), anodic stripping voltammetry and ionic liquid-microextraction (10). However, dispersive liquidliquid and supramolecular-based microextraction leads to a reduction in the use of organic solvents, provides low detection limits, and requires less time $(11,12)$.

\footnotetext{
*Corresponding autbor.

:E-mail: soylak@erciyes.edu.tr

Fax: +90 3524374933
}

\begin{abstract}
An analytical microextraction procedure was developed and applied for $\mathrm{Cu}$ (II) microextraction from natural waters, red pepper, black pepper, thyme, hashish, hair, and tobacco samples. The microextraction process was based on the chelation of $\mathrm{Cu}(\mathrm{II})$ from aqueous solutions with 4-(2-thiazolylazo) resorcinol, which is then moved to the organic supramolecular phase by ultrasonic waves. The organic phase, consisting of tetrahydrofuran and 1-decanol, was isolated by centrifugation. The extracted and preconcentrated copper was determined by microsampling flame atomic absorption spectrometry. The microextraction conditions and the operating parameters were optimized using the $\mathrm{pH}$ of 6 , $200 \mu \mathrm{L}$ of $0.1 \%$ of 4 -(2-thiazolylazo) resorcinol, and ultrasonic enhancement for 5 to 8 minutes. The ultrasound-assisted supramolecular solvent liquid phase microextraction procedure resulted in a limit of detection (LOD) of $1.13 \mu \mathrm{g} \mathrm{L}^{-1}$ and was applied for $\mathrm{Cu}$ (II) determination in samples with different matrices.
\end{abstract}

There are many studies in which preconcentration is used to determine copper. Tahera et al. (13) established solid phase extraction of copper and electrothermal atomic absorption spectrometry determination and reported a limit of detection (LOD) of $3.9 \mathrm{ng} \mathrm{L}^{-1}$. Niazi et al. (14) applied dispersive liquid-liquid microextraction of copper as dithizone chelates and a LOD of $2.6 \mathrm{ng} \mathrm{mL}^{-1}$. Yang et al. (15) compared ultrasound-assisted cloud point extraction and ultrasoundassisted dispersive liquid-liquid microextraction of copper with a limit of detection (LOD) of $0.7 \mu \mathrm{g} \mathrm{L}^{-1}$ and $0.8 \mu \mathrm{g} \mathrm{L}^{-1}$, respectively. Arain et al. (16) proposed non-dispersive ionic liquid microextraction for low level copper analysis resulting in a LOD of $0.042 \mathrm{mg} \mathrm{L}^{-1}$. Akhond et al. (17) developed gas-assisted dispersive liquid-phase microextraction for ultratrace level copper extraction with 1-hexyl-3-methylimidazolium hexafluorophosphate and a LOD of $0.07 \mathrm{mg} \mathrm{mL}^{-1}$. Arain et al. (18) applied an ionic liquid-assisted microemulsion procedure combined with cloud point extraction for copper determination in drinking water and serum and a LOD of $0.132 \mathrm{mg} \mathrm{L}^{-1}$. Ozzeybek et al. (19) used dispersive liquid-liquid microextraction coupled with FAAS for copper determination and reported a LOD of $0.7 \mu \mathrm{g} \mathrm{L}^{-1}$. Arain et al. (20) combined dispersive ionic liquid-based on ultrasoundassisted microextraction for trace level copper analysis with (PAN) 1-(2-pyridylazo)-2-naphthol chelation.

The combination of the microextraction processes with ultrasonic waves have resulted in a noticeable improvement due to the high dispersion of the targeted analyte with the aqueous and organic phases, allowing the transfer to the organic phase with the chelator (20). Furthermore, the supramolecular solvent is highly recommended for extraction applications (21-23). 
For the present study, a supramolecular solvent and ultrasonic waves were used to develop a liquid phase microextraction procedure for the separation and preconcentration of copper at ultratrace levels. Copper was determined by flame atomic absorption spectrometry (FAAS) which has a micro-sampling attachment for the accurate quantification of the analyte element in natural water, red pepper, black pepper, thyme, hashish, hair, and tobacco samples.

\section{EXPERIMENTAL}

\section{Instrumentation}

For the detection of copper, a PerkinElmer ${ }^{\circledR}$ AAnalyst $^{\mathrm{TM}} 300$ flame atomic absorption spectrometer (PerkinElmer, Inc., Shelton, CT, USA) was used. The extracted copper solutions were injected into the FAAS with a homemade injection system. A Teflon ${ }^{\circledR}$ funnel fixed with an Eppendorf ${ }^{\circledR}$ pipette was connected to the FAAS nebulizer. This system allows for the analysis of ultratrace determination of the extracted and preconcentrated copper samples $(24,25)$.

\section{Reagents}

A Millipore ${ }^{\circledR}$ Milli-Q ${ }^{\circledR}$ system (18.2 $\mathrm{M} \Omega \cdot \mathrm{cm}$, Millipore Corporation, USA) was used to obtain deionized water for solutions during the microextraction steps. In addition, the chemicals applied for the matrix and metal solutions as well as the organic solvents were of analytical grade. A Sartorius PT-10 pH meter (Germany) and a Sonorex DT-255 ultrasonic water bath (Germany) were used. An ALC PK 120 centrifuge (Buckinghamshire, England) was used during the microextraction processes.

\section{Test Procedure}

The sonication-based supramolecular solvent liquid phase microextraction procedure was performed in 50-mL polypropylene tubes into which the sample solutions including the targeted $\mathrm{Cu}$ (II) were placed. The $\mathrm{pH}$ was adjusted to the desired value by using a phosphate buffer. The 4-(2-thiazolylazo) resorcinol was used to chelate $\mathrm{Cu}(\mathrm{II})$, then tetrahydrofuran and 1-decanol were added to obtain the supramolecular solvent. The supramolecular microextraction step was enhanced by exposure to ultrasonic waves for about 5-8 minutes. The organic and aqueous phases were separated using the centrifuge at $4000 \mathrm{rpm}$ for 10 minutes. Then suction was applied to isolate the aqueous phase. The supramolecular phase containing the analyte was dissolved in ethanol to $500 \mu \mathrm{L}$ and the $\mathrm{Cu}$ concentration determined by micro-sampling FAAS.

\section{Application of Method to Water, Food, Hair, and Tobacco Samples and CRMs}

Red pepper, black pepper, thyme, hashish, hair, and tobacco samples were obtained in Kayseri, Turkey and subjected to a wet digestion method. In this method, $0.1-0.25 \mathrm{~g}$ of each sample was placed into a beaker and mixed with $20 \mathrm{~mL}$ of concentrated nitric acid. This mixture was heated until it formed a clear solution, then was filtered, and the final volume of the sample extract was completed to 10-mL volume with distilled water (8). Then the above-described microextraction method was applied.

For water analysis, the samples were also obtained in Kayseri, Turkey, and stored in polyethylene bottles. The samples consisted of wastewater, seawater, dam water, and valley water. Prior to use, the samples were first filtered with a cellulose membrane filter (Millipore Corporation, Bedford, MA, USA) (7-9). Then the above described method was applied. In addition, certified reference materials (CRMs) TMDA-64.2 and TMDA-53.3 Fortified Water (National Water Research
Institute, Environment Canada, Burlington, Canada) to demonstrate the accuracy of the proposed method.

\section{RESULTS AND DISCUSSION}

Evaluation of the Factors Controlling Ultrasound-assisted Supramolecular Solvent Liquid Phase Microextraction

By addition of 4-(2-thiazolylazo) resorcinol as the ligand to the sample solutions containing $\mathrm{Cu}(\mathrm{II})$, the interaction between the $\mathrm{OH}$ groups of the ligand and $\mathrm{Cu}(\mathrm{II})$ starts. $\mathrm{Cu}(\mathrm{II})$ interacts with the oxygen lone pair of electrons. This interaction of the concentration of $\mathrm{H}^{+}$ which is competing with $\mathrm{Cu}^{2+}$ and the $\mathrm{pH}$ are critical parameters for the extraction studies (26-30). In the present work, the effect of $\mathrm{H}^{+}$ is studied in terms of $\mathrm{pH}$ value. Different $\mathrm{pH}$ values from 2.0 to 8.0 were studied for the quantitative recovery of copper in the presented microextraction system. The efficiency of the extraction process was evaluated in each case, as is shown in Figure 1. The best microextraction condition was achieved at $\mathrm{pH} 6.0$ which was selected as optimal for further work.

The amount of 4-(2-thiazolylazo) resorcinol as ligand is critical to achieve high efficiency microextraction. Therefore, the amount of 4-(2-thiazolylazo) resorcinol was investigated using a volume of $0.1 \%$ 4-(2-thiazolylazo) resorcinol solution. The extraction efficiency using different 4-(2-thiazolylazo) resorcinol amounts is shown in Figure 2 . It can be seen that $200 \mu \mathrm{L}$ of $0.1 \%$ of 4 -(2-thiazolylazo) resorcinol is suitable for complete chelation of the targeted $\mathrm{Cu}$ (II) and leads to the transfer of all chelated Cu(II) to the organic phase in the next steps.

Composition of the supramolecular organic solvent was evaluated by testing the different ratios of 1-decanol and tetrahydrofuran, and 


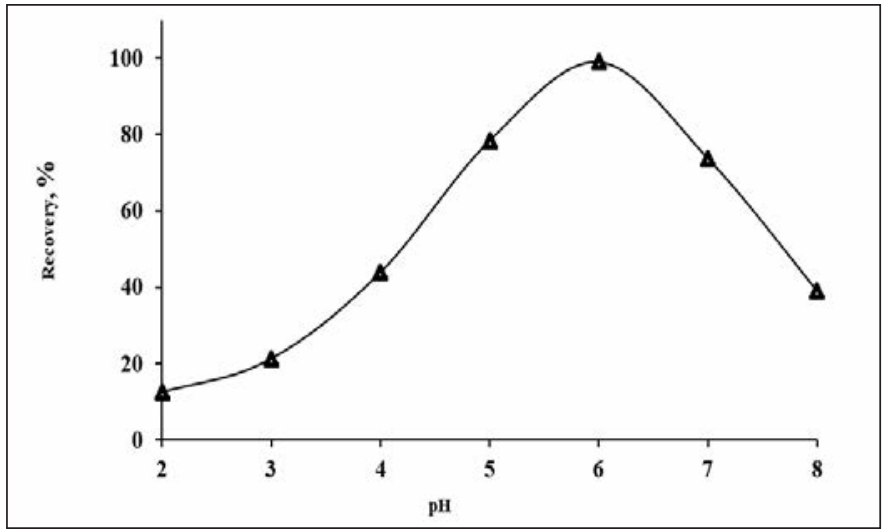

Fig. 1. Effect of the $p H$ on the recovery of $C u(I I)(N=3)$.

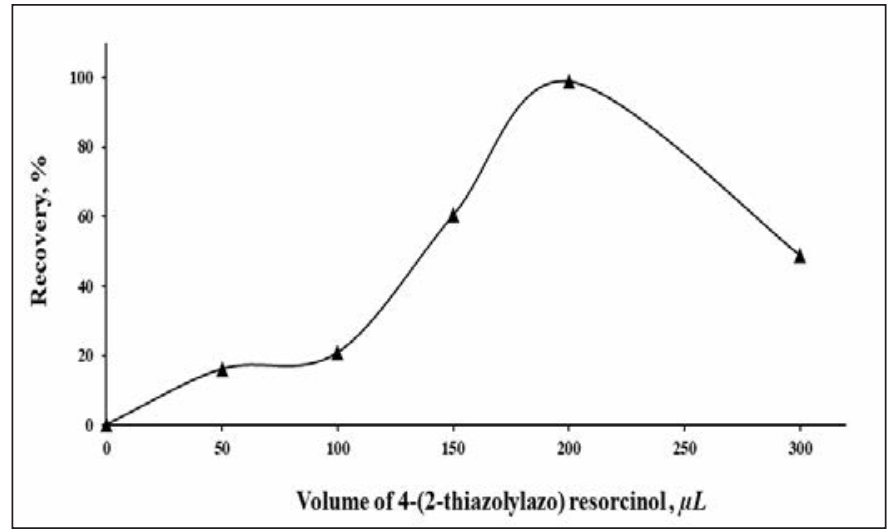

Fig. 2. Effect of ligand on the recovery of $\mathrm{Cu}(\mathrm{II})(\mathrm{N}=3)$.

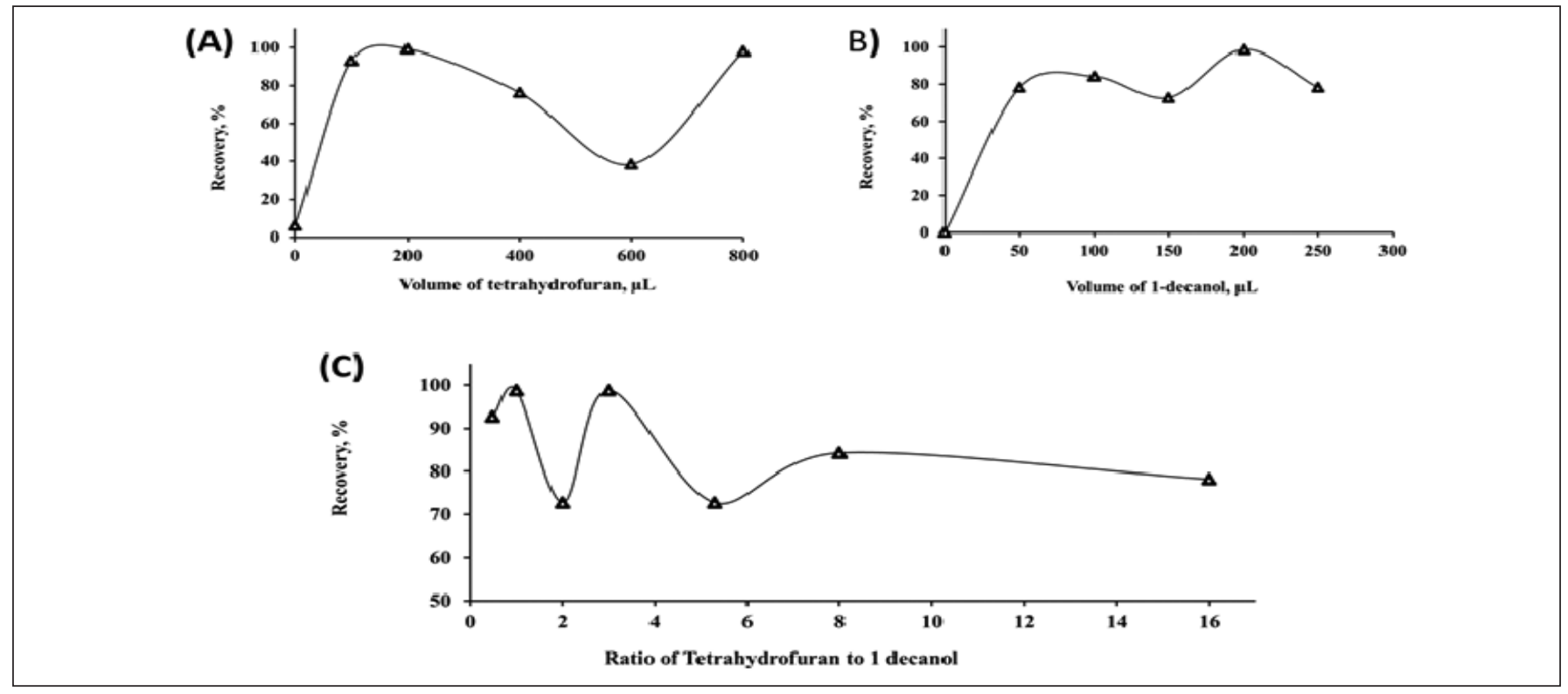

Fig. 3. Effect of the composition of supramolecular solvent on the recovery of $C u(I I)(N=3)$.

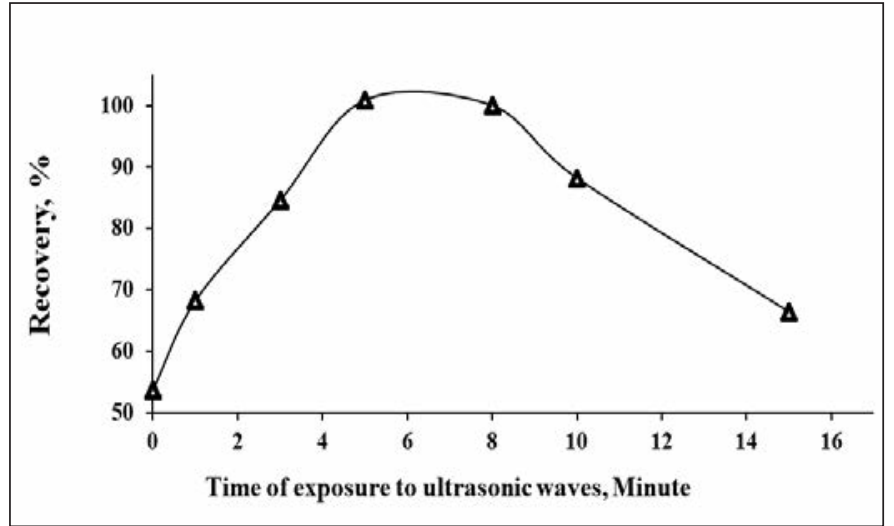

Fig. 4. Effect of exposure to ultrasonic waves on the recovery of $\mathrm{Cu}(\mathrm{II})(\mathrm{N}=3)$.

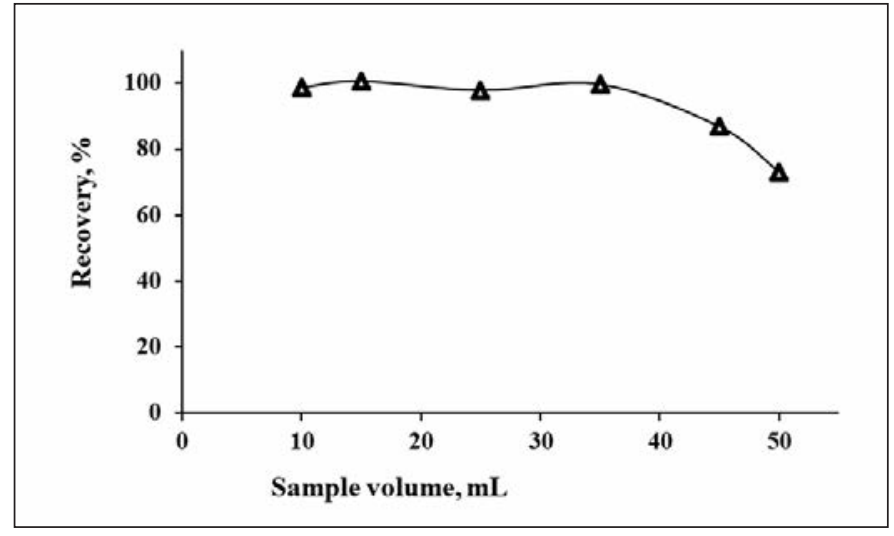

Fig. 5. Effect of sample volume on the recovery of $\mathrm{Cu}(\mathrm{II})(\mathrm{N}=3)$. 
evaluating the (\%) recovery in each case. Figure 3 shows the influence of tetrahydrofuran (A), the amount of 1-decanol (B), and the ratio between them $(C)$. It is clear that the suitable ratios of tetrahydrofuran and 1-decanol are 1 and 5.3.

The time required for dispersion under the ultrasonic-enhanced microextration was investigated. The effect of applying ultrasonic enhancement on the recovery of $\mathrm{Cu}$ (II) as 4-(2-thiazolylazo) resorcinol chelate in Figure 4 shows that between 5-8 minutes are suitable for best quantitative recoveries.

The sample volume (31-41) is another critical and important parameter to obtain quantitative recoveries and a high preconcentration factor in the extraction-separation studies. The influence of sample volume on the quantitative recoveries of $\mathrm{Cu}(\mathrm{II})$ was investigated. Figure 5 shows that the recoveries of copper are quantitative up to $35 \mathrm{~mL}$ of initial sample solution.

\section{Matrix Effects}

When designing the microextraction procedures, it is important to consider the capability of the analytical method to tolerate the presence of foreign ions rather than the targeted analyte (42-52). In the developed sonication-based supramolecular solvent liquid phase microextraction method, the effects of competition with various common ions were tested. The recoveries for each competing ion are listed in Table I. For all tested matrix ions, the recovery values of copper were in an acceptable quantitative range, suggesting the possibility of applying the presented microextraction process for real samples with different matrices.

\section{Analytical Evaluation}

The optimization of the sonication-based supramolecular solvent liquid phase microextraction method was extended and includes spiking known amounts of Cu(II) and a recovery evaluation to ensure the applicability of the process with different concentrations of $\mathrm{Cu}(\mathrm{II})$. Table II lists the results of the spiking-recovery tests which were found to be in the analytical quantitative range with a high recovery (\%). The accuracy of the developed method was also evaluated by analyzing CRM TMDA-64.2

TABLE I

Recovery of Cu(II) With Different Matrix Ions (N=3)

\begin{tabular}{lrlr}
\hline Ions & $\begin{array}{c}\text { Concentration } \\
(\mathrm{mg} / \mathrm{L})\end{array}$ & Added As & $\begin{array}{c}\text { Recovery } \\
(\%)\end{array}$ \\
\hline $\mathrm{K}^{+}$ & 1200 & $\mathrm{KCl}$ & $95 \pm 2$ \\
$\mathrm{Na}^{+}$ & 10,000 & $\mathrm{NaCl}$ & $97 \pm 3$ \\
$\mathrm{Mg}^{2+}$ & 400 & $\mathrm{Mg}\left(\mathrm{NO}_{3}\right)_{2} \cdot 6 \mathrm{H} 2 \mathrm{O}$ & $95 \pm 4$ \\
$\mathrm{Ca}^{2+}$ & 400 & $\mathrm{CaCl}$ & $97 \pm 0$ \\
$\mathrm{Co}^{2+}$ & 10 & $\mathrm{Co}\left(\mathrm{NO}_{3}\right)_{2}$ & $95 \pm 4$ \\
$\mathrm{Ni}^{2+}$ & 10 & $\mathrm{Ni}\left(\mathrm{NO}_{3}\right)_{2} \cdot 6 \mathrm{H}_{2} \mathrm{O}$ & $99 \pm 1$ \\
$\mathrm{Cd}^{2+}$ & 5 & $\mathrm{Cd}\left(\mathrm{NO}_{3}\right)_{2} \cdot 6 \mathrm{H}_{2} \mathrm{O}$ & $99 \pm 1$ \\
$\mathrm{Fe}^{3+}$ & 20 & $\mathrm{Fe}\left(\mathrm{NO}_{3}\right)_{3} \cdot 9 \mathrm{H}_{2} \mathrm{O}$ & $101 \pm 0$ \\
$\mathrm{Zn}^{2+}$ & 10 & $\mathrm{Zn}\left(\mathrm{NO}_{3}\right)_{2}$ & $95 \pm 1$ \\
$\mathrm{CO}_{3}^{2-}$ & 500 & $\mathrm{Na} \mathrm{CO}_{3}$ & $93 \pm 1$ \\
$\mathrm{Cl}^{-}$ & 1200 & $\mathrm{KCl}$ & $95 \pm 2$ \\
$\mathrm{SO}_{4}^{2-}$ & 500 & $\mathrm{Na} \mathrm{SO}_{4}$ & $101 \pm 1$ \\
$\mathrm{~F}^{-}$ & 200 & $\mathrm{NaF}$ & $95 \pm 2$ \\
\hline
\end{tabular}

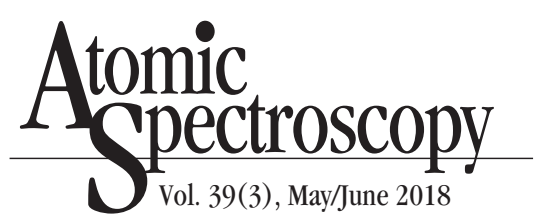

and TMDA-53.3 Fortified Water. The data in Table III indicate high agreement with the certified values. The preconcentration factor was calculated as 70 considering the initial sample volume of $35 \mathrm{~mL}$ and the final extracted analyte solution of $500 \mu \mathrm{L}(7,9)$.

In addition, the limit of detection (LOD), calculated based on 10 determinations of the standard deviation of the blank, was $1.13 \mu \mathrm{g} \mathrm{L}^{-1}$. The limit of quantification (LOQ), calculated as 3.3 times the LOD, was $3.40 \mu \mathrm{g} \mathrm{L}^{-1}$. The relative standard deviation (RSD) for 10 measurements was $4.6 \%$.

\section{Application of Method to Real Samples}

Monitoring pollution with environmental samples has become an important issue in analytical chemistry $(18,53-58)$. The health risk to humans and animals from surrounding environmental components has increased in the last decades due to fast urbanization and excessive industrial activities which leads to the release of heavy metals, including copper, into the environment. In addition, the probability of trans-

TABLE II

Spiking Cu(II) into Tap Water and Recovery $(\mathrm{N}=3)$

\begin{tabular}{|c|c|c|c|}
\hline $\begin{array}{l}\text { Added } \\
(\mu \mathrm{g})\end{array}$ & \multicolumn{2}{|c|}{$\begin{array}{l}\text { Found } \\
(\mu \mathrm{g})\end{array}$} & $\begin{array}{c}\text { Recovery } \\
(\%)\end{array}$ \\
\hline 0 & \multicolumn{2}{|l|}{0} & - \\
\hline 1.0 & \multicolumn{2}{|c|}{$1.00 \pm 0.08$} & 100 \\
\hline 2.0 & \multicolumn{2}{|c|}{$1.98 \pm 0.06$} & 99 \\
\hline \multicolumn{4}{|c|}{$\begin{array}{c}\text { TABLE III } \\
\text { Recovery of Cu(II) From } \\
\text { CRM Water Samples }(\mathrm{N}=3)\end{array}$} \\
\hline CRMs ( & $\begin{array}{l}\text { Certified } \\
\text { Value } \\
\left(\mu \mathrm{g} \mathrm{L}^{-1}\right)\end{array}$ & $\begin{array}{l}\text { Found } \\
\text { Value } \\
\left(\mu \mathrm{g} \mathrm{L}^{-1}\right)\end{array}$ & $\begin{array}{l}\text { Recovery } \\
(\%)\end{array}$ \\
\hline $\begin{array}{l}\text { TMDA- } \\
64.2\end{array}$ & 270 & $267 \pm 8$ & 98 \\
\hline $\begin{array}{l}\text { TMDA- } \\
53.3\end{array}$ & 312 & $297 \pm 7$ & 95 \\
\hline
\end{tabular}


TABLE IV

Application of Method to the Determination of $\mathrm{Cu}$ (II) in Water, Food, Hair, and Tobacco Samples $(\mathrm{N}=3)$

\begin{tabular}{llc}
\hline Samples & Sample Name & Cu Concentrations \\
\hline Water Samples $\left(\mu \mathrm{g} \mathrm{L}^{-1}\right)$ & Wastewater & $79.7 \pm 4.2$ \\
& Seawater & $67.9 \pm 4.2$ \\
& Dam Water & $48.7 \pm 10.5$ \\
& Valley Water & $39.8 \pm 6.3$ \\
Food Samples $\left(\mu \mathrm{g} \mathrm{kg}^{-1}\right)$ & Black Pepper & $38.3 \pm 0.0$ \\
& Thyme & $35.3 \pm 4.2$ \\
& Hashish & $30.9 \pm 2.1$ \\
Hair $(\mu \mathrm{g} \mathrm{kg}$ & Red Pepper & $54.6 \pm 10.5$ \\
Cigarettes $\left(\mu \mathrm{g} \mathrm{kg}^{-1}\right)$ & & $153.8 \pm 0.0$ \\
\hline
\end{tabular}

Mean \pm standard deviation.

ference of these pollutants into the food chain is high. It has also been reported that copper contaminates food, water, air, and other environmental samples. Hair samples are usually used to indicate copper exposure in the human body.

The samples analyzed in this study include natural water, red pepper, black pepper, thyme, hashish, hair, and tobacco samples. Their copper concentrations found are listed in Table IV. It can, therefore, be stated that the developed sonication-based supramolecular solvent liquid phase microextraction procedure is suitable for monitoring copper in samples from a variety of sources.

\section{CONCLUSION}

The application of ultrasonic waves in the present work has led to the effective microextraction of copper with a supramolecular solvent. For the microextraction of $\mathrm{Cu}(\mathrm{II})$, a 4-(2-thiazolylazo) resorcinol chelate was used which easily moved to the organic supramolecular solvent phase composed of tetrahydrofuran and 1-decanol. The proposed sonication-based supramolecular solvent liquid phase microextraction procedure was operated in low acidic medium at a pH of 6.0 using a phosphate buffer and provided a LOD of 1.13 $\mu \mathrm{g} \mathrm{L}^{-1}$. The presented microextraction method was successfully applied to the microextraction and determination of copper from different samples including natural waters, red pepper, black pepper, thyme, hashish, hair, and tobacco samples without any interference of other competing ions. The extracted and preconcentrated $\mathrm{Pb}$ (II) ions were determined by microsampling flame atomic absorption spectrometry.

\section{ACKNOWLEDGMENT}

The authors extend their sincere appreciation to the Deanship of Scientific Research at King Saud University for funding this Research Group - RGP-043.

$\overline{\text { Received October 31, } 2017 .}$

\section{REFERENCES}

1. E. Vanli, M.N. Misır, H. Alp, T. Ak, N. Özbek, Ü. Ocak, and M. Ocak, J. Fluoresc. 27, 1759 (2017).

2. H. Tapiero, and K.D. Tew, Biomed. Pharmacother. 57, 399 (2003).

3. J. Versieck, Trace Elements in Human Plasma for Serum, CRC
Press, Boca Raton, FL, USA (1989).

4. D. Bakircioglu, N. Topraksever, and Y.B. Kurtulus, J AOAC Int. 100, 1531 (2017)

5. D. Mendil, O.F. Unal, M. Tuzen, and M. Soylak, Food Chem. Toxicol. 48, 1383 (2010).

6. M. Soylak, Y.E. Unsal, and M. Tuzen, Environ. Monit. Assess. 185, 9663 (2013).

7. M. Soylak, M. Tuzen, A.S. Souza, M.G.A. Korn, and S.L.C. Ferreira, J. Hazard. Mater. 149, 264 (2007).

8. MA Habila, ZA ALOthman, AM ElToni, JP Labis, X Li, F Zhang, and M Soylak, Microchim. Acta 183, 2377 (2016).

9. Z.A. ALOthman, M.Habila, and E. Yilmaz, M. Soylak, J. AOAC Int., 96, 1425 (2013).

10. J. Abolhasani, M. Amjadi, and E.G. Kalhor, J. Chem. Health Risks 3, 292 (2013).

11. Z.A. ALOthman, M. Habila, E. Yilmaz, and M. Soylak, At. Spectrosc. 34, 175 (2013).

12. Z.A. Alothman, M.A. Habila, E. Yilmaz, M. Soylak, and S.M. Alfadul. At. Spectrosc. 37, 158 (2016).

13. M.A. Taher, Z. Daliri, and H. Fazelirad, Chin. Chem. Lett. 25, 649 (2014).

14. A. Niazi, S. Habibi, and M. Ramezani, Arab. J. Chem. 8, 706 (2015)

15. S. Yang, X. Fang, L. Duan, S. Yang, Z. Lei, and X. Wen. Spectrochim. Acta 148A, 72 (2015).

16. S.S. Arain, T.G. Kazi, H.I. Afridi, Naeemullah, K.D. Brahman, M.B. Arain, A.H. Panhwar, M.S. Arain, and $\mathrm{S}$. Baloch, J. Industrial Eng. Chem. 34, 27 (2016).

17. M. Akhond, G. Absalan, T. Pourshamsi, and A.M. Ramezani, Talanta 154, 461 (2016).

18. S.A. Arain, T.G. Kazi, H.I. Afridi, M.S. Arain, A.H. Panhwar, N. Khan, J.A. Baig, and F. Shah, Ecotoxicol. Environ. Safety 126, 186 (2016).

19. G. Ozzeybek, S. Erarpat, D.S. Chormey, M. Fırat, Ç. Büyükpınar, F. Turak, and S. Bakırdere, Microchem. J. 132, 406 (2017). 
20. M.S. Arain, T.G. Kazi, H.I. Afridi, J. Ali, and A. Akhtar, Ultrasonics Sonochem. 37, 23 (2017).

21. E. Yilmaz, and M. Soylak, Talanta, 126, 191 (2014).

22. Z. Li, J. Chen, M. Liu, and Y. Yang, Anal. Methods 6, 2294 (2014).

23. F. Aydin, E. Yilmaz, and M. Soylak, RSC Adv. 5, 40422 (2015)

24. M. Soylak, and E. Yilmaz, Desalination 275, 297 (2011).

25. S.R. Yousefi, and F. Shemirani, Anal. Chim. Acta 669, 251 (2010).

26. A. Daneshfar, M. Ghaedi, S. Vafafard, L. Shiri, R. Sahrai, and M. Soylak, Biol. Trace Elem. Res. 145, 240 (2012).

27. I. Narin, and M. Soylak, Talanta 60, 215 (2003).

28. S.Z. Mohammadi, D. Afzali, F. Sabermahani, and S. Afsharia, Quim. Nova, 37, 1436 (2014).

29. Z. AlOthman, Y.E. Unsal, M. Habila, A. Shabaka, M. Tuzen and M. Soylak, Anal. Lett. 48, 1738 (2015).

30. G. Alpdogan, and S.D. Zor, J. AOAC Int. 100, 1524 (2017).

31. M. Soylak, I. Narin, M. Dogan, Anal. Lett. 30, 2801 (1997).

32. A. Beiraghi and M. Shokri, Talanta 178, 616 (2018).

33. M. Tuzen, and M. Soylak, J. Hazard. Mater. 162, 724 (2009).

34. G. Vatankhah, M. Ebrahimi, and M. Kahani, Eurasian J. Anal. Chem. 12, 987 (2017).

35. I. Narin, M. Soylak, K. Kayakirilmaz, L. Elci, and M. Dogan, Anal. Lett. 35, 1437 (2002).

36. R. Hakimelahi, and K. Niknam, Eurasian J. Anal. Chem. 12, 963 (2017).

37. U. Divrikli, A.A. Kartal, M. Soylak, and L. Elci, J. Hazard. Mater. 145, 459 (2007).

38. H. Celebi, and O. Gok, Sigma J. Eng. Natural Sci. 35, 69 (2017).

39. Z.A. ALOthman, E. Yilmaz, M. Habila, and M. Soylak, Turk. J. Chem. 39, 1038 (2015).

40. S. Yildiz, M. Cekim, and T. Dere, Appl. Biochem. Biotechnol. 183, 332 (2017).
41. H. Serencam, V.N. Bulut, M. Tufekci, A. Gundogdu, C. Duran, S. Hamza, and M. Soylak, Int. J. Environ. Anal. Chem. 93, 1484 (2013).

42. M. Roushani, Z. Saedi, F. Hamdi, and B.Z. Dizajdizi, J. Electroanal. Chem. 804, 1 (2017).

43. F. Pouya, M. Arabi, and G. Absalan, Appl. Organometal. Chem. 32, e4040 (2018).

44. S. Saracoglu, M. Soylak, L. Elci, and M. Dogan, Anal. Lett. 35, 2603 (2002).

45. S.M. Yousefi, and F. Shemirani, Int. J. Environ. Anal. Chem. 97, 1065 (2017).

46. E. Kazemi, A.M.H. Shabani, and S. Dadfarnia, F. Izadi, Int. J. Environ. Anal. Chem. 97, 1080 (2017).

47. G.N. Wang, N.P. Wu, X. He, H.C. Zhang, J. Liu, and J.P. Wang, J. Chromatogr. 1067B, 18 (2017).

48. M. Eftekhari, M. Gheibi, M. Akrami, and F. Iranzad, New J. Chem. 42, 1159 (2018).

49. M. Soylak, L. Elci, and M. Dogan, J. Trace Microprobe Techn. 17, 149 (1999).

50. S. Saracoglu, M. Soylak, and L. Elci, Talanta, 59, 287 (2003).

51. A. Baysal, C. Kuznek, and M. Ozcan, Int. J. Environ. Anal. Chem. 98, 45 (2018).

52. A. Shokrollahi, M. Ghaedi, O. Hossaini, N. Khanjari, and M. Soylak, J. Hazard. Mater. 160, 435 (2008).

53. N. Jalbani, S. Bhutto, S. Rahujo, and F. Ahmed, Mediterranean J. Chem. 4, 309 (2015).

54. A. Akdogan, U. Divrikli, M. Soylak, and L. Elci, At. Spectrosc. 37, 25 (2016).

55. A.M. Massadeh, A.A.T. Al-Massaedh, and S. Kharibeh, Environ. Sci. Pollut. Res. 25, 3501 (2018).

56. S. Erdogan, S. Erdemoglu, and S. Gücer, J. Nutr. Food. Sci. 7, 6 (2017).

57. S.M. Sorouraddin, M.A. Farajzadeh, and M. Ghorbani, Int. J. Environ. An. Ch. 98, 182 (2018).

58. M.A. Habila, Z.A. ALOthman, E. Yilmaz, and M. Soylak, Int. J.
Environ. An. Ch. 98, 171 (2018). 